\title{
Utilization and Metabolism of NAD by Haemophilus parainfluenzae
}

\author{
By MICHAEL H. CYNAMON, * TIMOTHY B. SORG† AND \\ ALAN PATAPOW \\ Department of Medicine, Veterans Administration Medical Center, State University of New \\ York, Health Science Center, Syracuse, NY 13210, USA
}

(Received 23 March 1988)

\begin{abstract}
The utilization of exogenous nicotinamide adenine dinucleotide (NAD) by Haemophilus parainfluenzae was studied in suspensions of whole cells using radiolabelled NAD, nicotinamide mononucleotide (NMN), and nicotinamide ribonucleoside (NR). The utilization of these compounds by $H$. parainfluenzae has the following characteristics. (1) NAD is not taken up intact, but rather is degraded to NMN or NR prior to internalization. (2) Uptake is carriermediated and energy-dependent with saturation kinetics. (3) There is specificity for the $\beta$-configuration of the glycopyridine linkage. (4) An intact carboxamide group is required on the pyridine ring. The intracellular metabolism of NAD was studied in crude cell extracts and in whole cells using carbonyl- ${ }^{14} \mathrm{C}$-labelled NR, NMN, NAD, nicotinamide, and nicotinic acid as substrates in separate experiments. A synthetic pathway from NR through NMN to NAD that requires $\mathrm{Mg}^{2+}$ and ATP was demonstrated. Nicotinamide was found as an end-product of NAD degradation. Nicotinic acid mononucleotide and nicotinic acid adenine dinucleotide were not found as intermediates. The NAD synthetic pathway in $H$. parainfluenzae differs from the Preiss-Handler pathway and the pyridine nucleotide cycles described in other bacteria.
\end{abstract}

\section{INTRODUCTION}

NAD is an essential coenzyme in cellular oxidation-reduction reactions. Most prokaryotes and eukaryotes are capable of synthesizing NAD de novo utilizing dihydroxyacetone phosphate and aspartate, formate and aspartate or tryptophan (Foster \& Moat, 1980). These pathways produce quinolinic acid (QA) as an intermediate and each terminate in the common pathway shown in Fig. 1. The intracellular biosynthetic pathway of NAD has been well studied in Salmonella typhimurium and Escherichia coli (Foster \& Moat, 1980). In these and most other prokaryotic cells dihydroxyacetone phosphate condenses with aspartic acid to form QA (Chandler \& Gholson, 1972; Foster \& Moat, 1980). The QA is converted to nicotinic acid mononucleotide (NAMN) in the presence of 5 -phosphoribosyl pyrophosphate (PRPP). The NAMN reacts with ATP to form nicotinic acid adenine dinucleotide (NAAD) which forms NAD with the addition of an amino group from glutamine. This pathway does not exist in Haemophilus species that require exogenous NAD for growth.

In addition to the de novo synthetic pathways, several salvage pathways known as the pyridine nucleotide cycles (PNCs) have been described that allow some cells to utilize pre-formed pyridine bases such as nicotinamide (Nam), nicotinic acid, or nicotinamide mononucleotide (NMN) when they are available (Foster, 1981; Hillyard et al., 1981). These pyridine bases may be obtained from the breakdown of intracellular NAD or from exogenous sources.

† Present address: Department of Medicine, Veterans Administration Medical Center, 4100 W. Third St, Dayton, OH 45428, USA.

Abbreviations: QA, quinolinic acid; NAMN, nicotinic acid mononucleotide; NAAD, nicotinic acid adenine dinucleotide; PNC, pyridine nucleotide cycle; NMN, nicotinamide mononucleotide; PRPP, 5'-phosphoribosyl pyrophosphate; Nam, nicotinamide; NR, nicotinamide ribonucleoside; TNAD, thionicotinamide adenine dinucleotide; $\mathrm{N}\left[\mathrm{U}-{ }^{14} \mathrm{C}\right] \mathrm{AD}$, nicotinamide $\left[\mathrm{U}-{ }^{14} \mathrm{C}\right]$ adenine dinucleotide. 


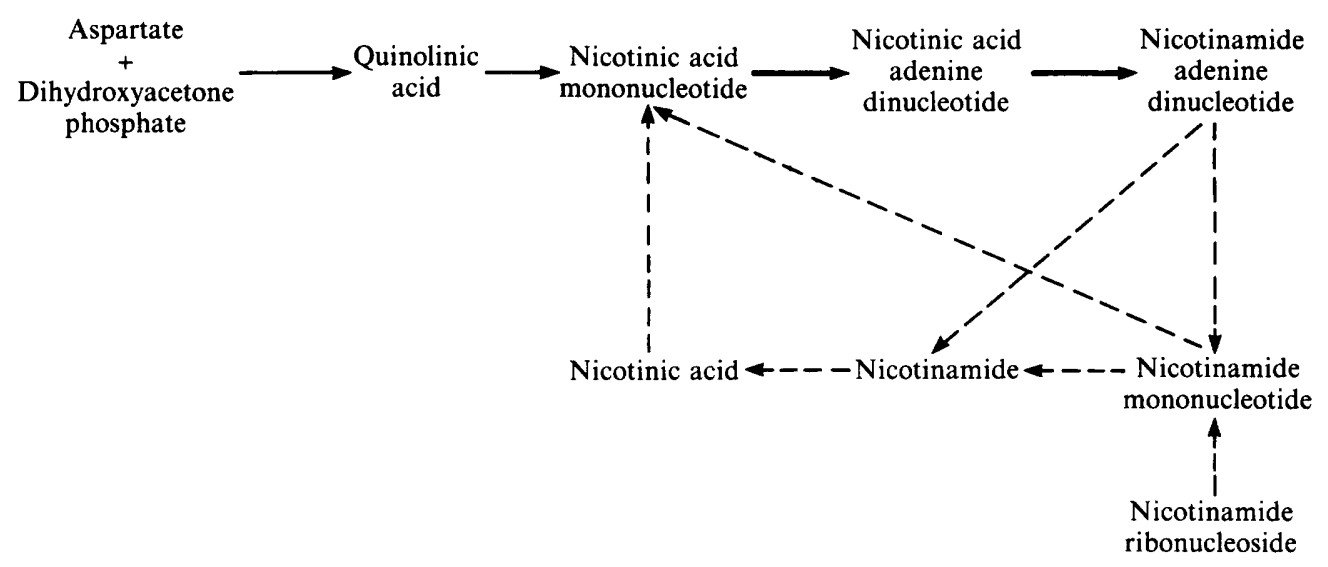

Fig. 1. NAD metabolism in aerobic bacteria. The solid arrows indicate the Preiss-Handler pathway (Preiss \& Handler, 1958 a,b), with the common pathway in bold arrows. The dashed arrows represent alternative PNCs described in S. typhimurium (Foster \& Moat, 1980; Hughes et al.,1983; Liu et al., 1982). NR can be utilized as an exogenous source of pyridine for the synthesis of NAD via one of the two pathways shown.

There has been little attention paid to the utilization of exogenous NAD or to the synthetic and degradative pathway of NAD in Haemophilus parainfluenzae or Haemophilus influenzae. These organisms are of interest because they are important human pathogens. They are generally considered to require exogenous $\beta$-NAD for growth (Killian, 1980). Nicotinamide ribonucleoside (NR) or NMN can also support growth; however, 3-acetylpyridine adenine dinucleotide, 3-acetylpyridine ribonucleoside, nicotinamide glucoside, nicotinamide pyranoside, $\alpha$-NAD, nicotinic acid, and Nam do not support growth (Bachur \& Kaplan, 1955). These growth requirements suggest that NR or possibly NMN are the metabolites that enter the cell and serve as substrates for the intracellular synthesis of NAD.

The purpose of this study was to characterize the utilization of exogenous NAD and to examine the intracellular metabolism of NAD in $H$. parainfluenzae. We showed that NAD is hydrolysed to NMN and subsequently to NR (Cynamon et al., 1985). The latter compound is internalized and converted intracellularly to NAD via NMN (Sorg et al., 1986).

\section{METHODS}

Organism and culture media. The $H$. parainfluenzae strain used in our studies was a clinical isolate obtained from the Microbiology Laboratory at the Veterans Administration Medical Center, Syracuse, NY. This organism grew optimally in $1 \mu \mathrm{M}-\mathrm{NAD}$ and $5 \mu \mathrm{M}-\mathrm{NMN}$ or NR. It did not grow in Nam, NAAD, or NAMN, even at concentrations as high as $100 \mathrm{mM}$. A chemically defined medium (MIc) which supports rapid growth of H. influenzae (Herriot et al., 1970) was used with the following modifications : polyvinyl alcohol, nitriloethanol and haemin were omitted; oleic acid was added to a final concentration of $20 \mu \mathrm{g} \mathrm{ml}^{-1}$. Bacteria were titrated on chocolate agar plates (BBL).

Chemicals and reagents. $\beta$-NAD, $\beta$-NMN, $\beta$-NAAD, $\beta$-NAMN, $\alpha$-NAD, $\alpha$-NMN, Nam, nicotinic acid, ATP, AMP and PRPP were obtained from Sigma. Thionicotinamide adenine dinucleotide (TNAD) was obtained from P-L Biochemicals. Nicotinamide[U-14 C]adenine dinucleotide (N[U-14 C]AD) (uniform labelled adenine) [carbonyl $\left.{ }^{14} \mathrm{C}\right] \mathrm{NAD},\left[\right.$ carbonyl $\left.{ }^{14} \mathrm{C}\right]$ nicotinamide and $\left[\right.$ carbonyl $\left.{ }^{14} \mathrm{C}\right]$ nicotinic acid were obtained from Amersham. Their specific activities were $269 \mathrm{mCi} \mathrm{mmol}^{-1}\left(9.95 \mathrm{GBq} \mathrm{mmol}^{-1}\right), 53 \mathrm{mCi} \mathrm{mmol}^{-1}\left(1.96 \mathrm{GBq} \mathrm{mmol}^{-1}\right), 56 \mathrm{mCi}^{-1}$ $\mathrm{mmol}^{-1}\left(2.07 \mathrm{GBq} \mathrm{mmol}^{-1}\right)$ and $56 \mathrm{mCi} \mathrm{mmol}^{-1}\left(2.07 \mathrm{GBq} \mathrm{mmol}^{-1}\right)$, respectively. The [carbonyl- $\left.{ }^{14} \mathrm{C}\right] \mathrm{NAD}$ utilized in the uptake studies was at a final concentration of $0.15 \mu \mathrm{M}$ and a specific activity of $24 \mu \mathrm{Ci} \mu \mathrm{mol}^{-1}(0.88$ $\mathrm{MBq} \mathrm{mmol}^{-1}$ ) except where indicated.

[carbonyl $\left.{ }^{14} \mathrm{C}\right] \mathrm{NMN}$ was prepared from $\left[\right.$ carbonyl $\left.-{ }^{14} \mathrm{C}\right] \mathrm{NAD}$ by treatment with snake venom phosphodiesterase (Calbiochem-Behring) or NAD pyrophosphatase (Sigma) in Tris/ $\mathrm{HCl}$ buffer $\mathrm{pH} 7 \cdot 5$. $\left[\right.$ carbonyl $\left.{ }^{-14} \mathrm{C}\right] \mathrm{NR}$ was made by adding alkaline phosphatase (Calbiochem-Behring) to the above reaction mixture. The labelled NMN was purified by reversed-phase HPLC using a $\mathrm{C}_{18} \mu$ Bondapack column and a Waters system equipped with a UV detector, a fraction collector, and a model 660 solvent programmer. A concave gradient (curve no. 7) from 0 to $30 \%$ 
was developed over $40 \mathrm{~min}$, using $0.02 \mathrm{M}-\mathrm{KH}_{2} \mathrm{PO}_{4}$ as the weak solvent and $60 \%$ methanol in water as the strong solvent, with a flow rate of $1.0 \mathrm{ml} \mathrm{min} \mathrm{mi}^{-1}$ (Miksic \& Brown, 1977). The labelled NR was purified by passing the reaction mixture over a column of anion-exchange resin AG 1-X8 (200-400 mesh) in the formate form (Bio-Rad) using water as the eluent (Kasarov \& Moat, 1972). The final product still contained 5-10\% Nam as determined by thin layer chromatography (TLC).

$T L C$. Three TLC systems were used to separate the various NAD metabolites. Solvent system A was $0 \cdot 05 \mathrm{M}$ $\mathrm{KH}_{2} \mathrm{PO}_{4}$ (adjusted to $\mathrm{pH} 3.0$ with concentrated $\left.\approx 17 \mathrm{M}-\mathrm{H}_{3} \mathrm{PO}_{4}\right) 100 \%$ (absolute) methanol $(9: 1, \mathrm{v} / \mathrm{v}$ ). Solvent system B was $1 \mathrm{M}$-ammonium acetate (adjusted to $\mathrm{pH} 5 \cdot 0$ with concentrated $\mathrm{HCl} / 95 \%$ ethanol $(7: 3, \mathrm{v} / \mathrm{v})$. Solvent system $\mathrm{C}$ was $0 \cdot 2 \mathrm{M}-\mathrm{LiCl}_{2}$. The solid phase for the former two systems was cellulose acetate (Kodak) and PEI cellulose (Merck) for the latter. The $R_{F}$ values for system A were: Nam, 0.84 ; nicotinic acid, $0.93 ; \mathrm{NR}, 0.75$; NMN, 0.78; and NAD, 0.78 . For systems B and C respectively the $R_{F}$ values were: Nam, 0.85 and 0.70 ; nicotinic acid, 0.85 and $0.45 ; \mathrm{NR}, 0.70$ and 0.85 ; NMN, 0.45 and 0.71 ; NAMN, 0.45 and 0.25 ; NAD, 0.20 and 0.37 ; and NAAD, $\mathbf{0 . 3 5}$ and $\mathbf{0} \cdot 20$. System A separated Nam from nicotinic acid and was used to assay nicotinamidase activity. System B separated NAD, NMN, NR, and Nam (Kasarov \& Moat, 1972), and was used to assay NAD synthesis and degradation. System $C$ separated the deaminated metabolites NAMN and NAAD from the other compounds and was used to detect their presence.

Specimens and standard markers were loaded in separate lanes on commercially prepared, plastic-backed TLC plates containing fluorescent indicators. The plates were developed in the appropriate solvents, dried, and the standards were visualized under UV light. The lane for each specimen was cut at intervals corresponding to the standards and each section was placed in scintillation counting vials with $10 \mathrm{ml}$ Betafluor (National Diagnostics) for measurement of the radioactivity.

Uptake studies. $H$. parainfluenzae was grown overnight in MIc medium supplemented with $6 \mu \mathrm{M}-\mathrm{NAD}$. The cells were washed twice with $50 \mathrm{~mm}$-potassium phosphate buffer, $\mathrm{pH} 7 \cdot 0$, followed by centrifugation, and then resuspended at a final concentration of approximately $10^{8} \mathrm{c}$.f.u. $\mathrm{ml}^{-1}$ in the same buffer supplemented with $5 \mathrm{mM}$ glucose and $10 \mathrm{~mm}-\mathrm{MgSO}_{4}$. The suspension was incubated for $5 \mathrm{~min}$ at $37^{\circ} \mathrm{C}$ on a rotary shaker. Radiolabelled NAD was then added and triplicate $0.5 \mathrm{ml}$ samples were removed immediately and after $10 \mathrm{~min}$, except where indicated. The samples were filtered through GA6 0.45 $\mu \mathrm{m}$ membrane filters (Gelman Sciences), which had been soaked in $50 \mathrm{~mm}$-potassium phosphate buffer (pH 7.0) with $1.5 \mu \mathrm{M}-\mathrm{NAD}$. The filters were washed twice with $5 \mathrm{ml}$ of the NAD-containing phosphate buffer then placed in scintillation vials containing $10 \mathrm{ml}$ of Filtron-X (National Diagnostics) and radioactivity counted by liquid scintillation. Samples of the cell suspensions were titrated in duplicate on chocolate agar to determine the initial cell count. Results are expressed as ${ }^{14} \mathrm{C}$-labelled metabolite uptake as a percentage of the control or as pmol $\mathrm{min}^{-1}\left(10^{8} \mathrm{c.f} . \mathrm{u} \text {. }\right)^{-1}$ The kinetics of uptake were analysed by the method of Lineweaver and Burk (Lineweaver \& Burk, 1934; Michal, 1978). Uptake experiments were also done in the presence of various unlabelled NAD metabolites and the rates of uptake for radiolabelled Nam, NR, NMN, and NAD were compared.

$N A D$ breakdown by whole cells of $H$. parainfluenzae. Cells were prepared in the same manner as for the uptake studies described above. The cells were suspended to a final concentration of $8 \times 10^{8} \mathrm{c.f} . \mathrm{u}$. $\mathrm{ml}^{-1}$ and uptake studies done under three conditions: (1) $10 \mathrm{mM}-\mathrm{Mg}^{2+}$ and $5 \mathrm{mM}$-glucose in $50 \mathrm{mM}$-phosphate buffer, pH $7 \cdot 0$, at $37^{\circ} \mathrm{C}$; (2) $10 \mathrm{~mm}-\mathrm{Mg}^{2+}$ and $0.2 \mathrm{mM}$-2,4-dinitrophenol in $50 \mathrm{~mm}$-phosphate buffer, pH 7.0, at $37^{\circ} \mathrm{C}$, and (3) $50 \mathrm{~mm}$-phosphate buffer, $\mathrm{pH} 7 \cdot 0$, at $4{ }^{\circ} \mathrm{C}$. The cells were incubated at these temperatures for $5 \mathrm{~min}$ and $\left[\right.$ carbonyl $\left.-1{ }^{14} \mathrm{C}\right] \mathrm{NAD}$ with a specific activity of $4.1 \mu \mathrm{Ci} \mu \mathrm{mol}^{-1}\left(0.15 \mathrm{MBq}^{-1} \mathrm{~mol}^{-1}\right)$ was then added to a final concentration of $0.25 \mu \mathrm{Ci} \mathrm{ml}^{-1}$ to initiate the reaction. Single $0.5 \mathrm{ml}$ samples were removed at $0,10,30,120$, and 300 min and vacuum filtered as in the uptake studies except that the filtrate from each sample was collected before the filters were washed. The ${ }^{14} \mathrm{C}$ labelled compounds in the filtrates were analysed by TLC with solvent system B. The filters were washed, placed in Filtron-X, and the radioactivity in the cells was measured.

Crude bacterial extracts. The cell-free extracts used in the metabolism experiments were prepared by growing the organism overnight in Todd-Hewitt broth (BBL) supplemented with $5 \mu \mathrm{g} \mathrm{m}^{-1}$ NAD. The cells were pelleted, washed twice with $50 \mathrm{~mm}$-phosphate buffer $\mathrm{pH} 7.0$ and resuspended in the same buffer. The cells were broken in a Cell Homogenizer MSK (Braun) using $0 \cdot 1 \mathrm{~mm}$ glass beads. The extracts were centrifuged at $6000 \mathrm{~g}$ for $10 \mathrm{~min}$, then the supernatant was centrifuged at $30000 \mathrm{~g}$ for $10 \mathrm{~min}$ and filtered through a GA6 $0.22 \mu \mathrm{m}$ membrane filter (Gelman). The typical protein concentration was about $12 \mathrm{mg} \mathrm{ml}^{-1}$ as determined by the Bio-Rad assay (Bio-Rad). The crude extracts were stored at $-70{ }^{\circ} \mathrm{C}$.

Enzymic reactions with crude extracts. The standard reaction mixture for the assay of NAD synthesis contained 1-2 mg crude extract protein $\mathrm{ml}^{-1}$ in $50 \mathrm{~mm}$-Tris/ $\mathrm{HCl}$ buffer, $\mathrm{pH} 7.0$ at $37^{\circ} \mathrm{C} . \mathrm{MgCl}_{2}$ and ATP were added at final concentrations of $2 \mathrm{mM}$ and $4 \mathrm{~mm}$ respectively. The appropriate carbonyl ${ }^{14} \mathrm{C}$-labelled substrate (NR, NMN, Nam or nicotinic acid) was added to a final concentration of approximately $0.5 \mu \mathrm{Ci} \mathrm{ml}^{-1}$ to start the reaction. The specific activities of the substrates were between 44 and $56 \mu \mathrm{Ci} \mu \mathrm{mol}^{-1}$. When Nam or nicotinic acid were used as substrates, PRPP (12 mM) was added as a source of ribosyl phosphate, and glutamine ( $2 \mathrm{mM}$ ) was added as an amine donor when nicotinic acid was the substrate. A $50 \mu 1$ sample was removed from the mixture at $0,5,10$, and $20 \mathrm{~min}$ and heated at $100^{\circ} \mathrm{C}$ for 2-3 min to stop the reaction. Each sample was analysed by TLC. 
NAD degradation and NMN deamidase activity were assayed using similar concentrations of cell extract, Tris/ $\mathrm{HCl}$ buffer, and substrate (NAD or NMN) in the absence of $\mathrm{Mg}^{2+}$ and ATP. Boiled cell extracts were used as controls.

Extraction of radiolabelled intracellular components from whole cells. $H$. parainfluenzae was grown overnight in MIc broth. The cells were pelleted, washed, and resuspended to a concentration of approximately $5 \times 10^{8}$ c.f.u. $\mathrm{ml}^{-1}$ in $50 \mathrm{~mm}$-phosphate buffer $\mathrm{pH} 7.0,10 \mathrm{~mm}-\mathrm{MgSO}_{4}$, and $5 \mathrm{~mm}$-glucose. The final volume of the suspension was $10 \mathrm{ml}$. [carbonyl ${ }^{-14} \mathrm{C}$ ]NR was added to a final concentration of $0.13 \mu \mathrm{Ci} \mathrm{ml}^{-1}$ and the cells were incubated at $37^{\circ} \mathrm{C}$. Samples $(2 \mathrm{ml})$ were removed at various times, and the cells were collected on $0.45 \mu \mathrm{m}$ membrane filters and washed with phosphate buffer. The filters were placed in a vial with $5 \mathrm{ml}$ cold toluene/water $(5: 95, \mathrm{v} / \mathrm{v})$ and shaken vigorously to extract the intracellular components (Kay, 1971). The extracts were lyophilized, and the residue was dissolved in $0.2 \mathrm{ml}$ water and analysed by TLC.

\section{RESULTS}

\section{Uptake of ${ }^{14} \mathrm{C}$-labelled metabolite from $\left[\right.$ carbonyl $\left.-{ }^{14} \mathrm{C}\right] N A D$}

The uptake of ${ }^{14} \mathrm{C}$-labelled metabolite from [carbonyl $\left.{ }^{-14} \mathrm{C}\right] \mathrm{NAD}$ by $H$. parainfluenzae at $37^{\circ} \mathrm{C}$ required glucose and was further enhanced by $\mathrm{Mg}^{2+}$ (Table 1$)$. There was no measurable uptake of label when the cells were incubated at $4{ }^{\circ} \mathrm{C}$ in the buffer with glucose or with glucose and $\mathrm{Mg}^{2+}$. The uptake of label was linear during the initial $16 \mathrm{~min}$ (Fig. $2 a$ ). By $16 \mathrm{~min} 25 \%$ of the added label had been sequestered by the cells. The initial rate of uptake of ${ }^{14} \mathrm{C}$-labelled metabolite from [carbonyl $\left.-{ }^{14} \mathrm{C}\right] \mathrm{NAD}$ was measured at various NAD concentrations (Fig. $3 a$ ). A maximal rate of uptake was approached at concentrations of NAD above $4 \mu \mathrm{M}$. A double reciprocal plot of the uptake of ${ }^{14} \mathrm{C}$-labelled metabolite from labelled NAD as a function of NAD concentration is shown in the inset of Fig. 3(a). This analysis gives a $K_{\mathrm{m}}$ of $0.55 \mu \mathrm{M}$ and a $V_{\max }$ of $2 \cdot 4 \mathrm{pmol} \min ^{-1}\left(10^{8} \text { c.f.u. }\right)^{-1}$.

\section{Effect of metabolic inhibitors on ${ }^{14} \mathrm{C}$-labelled metabolite uptake from [carbonyl-14 C]NAD}

The effect of KCN, 2-deoxyglucose, sodium azide and 2,4-dinitrophenol (DNP) on the uptake of ${ }^{14} \mathrm{C}$-metabolite from [carbonyl $-{ }^{14} \mathrm{C}$ ]NAD is illustrated in Table 1. DNP and 2-deoxyglucose inhibited uptake to a much greater extent than did $\mathrm{KCN}$ or sodium azide. Since the ${ }^{14} \mathrm{C}$-labelled metabolite uptake required glucose and was inhibited by both DNP and 2-deoxyglucose, it appears that uptake is energy dependent.

\section{Table 1. Effect of glucose and $\mathrm{Mg}^{2+}$ or metabolic inhibitors on uptake of ${ }^{14} \mathrm{C}$-metabolite from} $\left[\right.$ carbonyl $\left.-{ }^{14} \mathrm{C}\right] \mathrm{NAD}$

Uptake was measured in the presence of $0 \cdot 15 \mu \mathrm{M}-\mathrm{NAD}$ with a specific activity of $48000 \mathrm{c.p} . \mathrm{m} . \mathrm{nmol}^{-1}$. The uptake of ${ }^{14} \mathrm{C}$-labelled metabolite in the presence of glucose and $\mathrm{Mg}^{2+}$ was $0.59 \mathrm{pmol} \mathrm{min}-1\left(10^{8}\right.$ c.f.u. $)^{-1}$. The data are the mean of triplicate samples; SD values were less than $5 \%$ of the mean.

$\begin{array}{cc} & \text { Uptake of } \\ & 14 \text { C-labelled } \\ \text { Composition of medium } & \text { melite } \\ \text { Cof control })\end{array}$

\begin{tabular}{|c|c|}
\hline $\begin{array}{l}50 \text { mM-Phosphate buffer, pH } 7 \cdot 0 \\
50 \mathrm{mM} \text {-Phosphate buffer, pH } 7 \cdot 0+5 \mathrm{mM} \text {-glucose } \\
50 \mathrm{mM} \text {-Phosphate buffer, pH } 7 \cdot 0+10 \mathrm{mM}-\mathrm{Mg}^{2+} \\
50 \mathrm{mM}-\text { Phosphate buffer, pH } 7 \cdot 0+5 \mathrm{mM} \text {-glucose }+10 \mathrm{mM}-\mathrm{Mg}^{2+}\end{array}$ & $\begin{array}{r}<2 \\
29 \\
<2 \\
100\end{array}$ \\
\hline Metabolic inhibitor* & \\
\hline $\begin{array}{l}20 \mathrm{mM}-2 \text {-Deoxyglucose } \\
1 \mathrm{mM}-\mathrm{KCN}\end{array}$ & $\begin{array}{l}14 \\
89\end{array}$ \\
\hline $10 \mathrm{mM}$-Sodium azide & 59 \\
\hline $0 \cdot 2 \mathrm{~mm}-\mathrm{DNP} \dagger$ & 4 \\
\hline
\end{tabular}

* Cells were suspended in $50 \mathrm{~mm}$-potassium phosphate buffer, pH 7.0, $5 \mathrm{~mm}$-glucose and $10 \mathrm{~mm}-\mathrm{MgSO}_{4}$. The metabolic inhibitor was incubated for $5 \mathrm{~min}$ with the cell suspension prior to addition of labelled NAD (final concentration $0 \cdot 15 \mu \mathrm{M}$ with a specific activity of 48000 c.p.m. nmol ${ }^{-1}$ ). The uptake of ${ }^{14} \mathrm{C}$-labelled metabolite under control conditions was $0.59 \mathrm{pmol} \min ^{-1}\left(10^{8} \text { c.f.u. }\right)^{-1}$.

$\dagger$ This concentration of DNP was not lethal to $H$. parainfluenzae after a 15 min incubation period. 

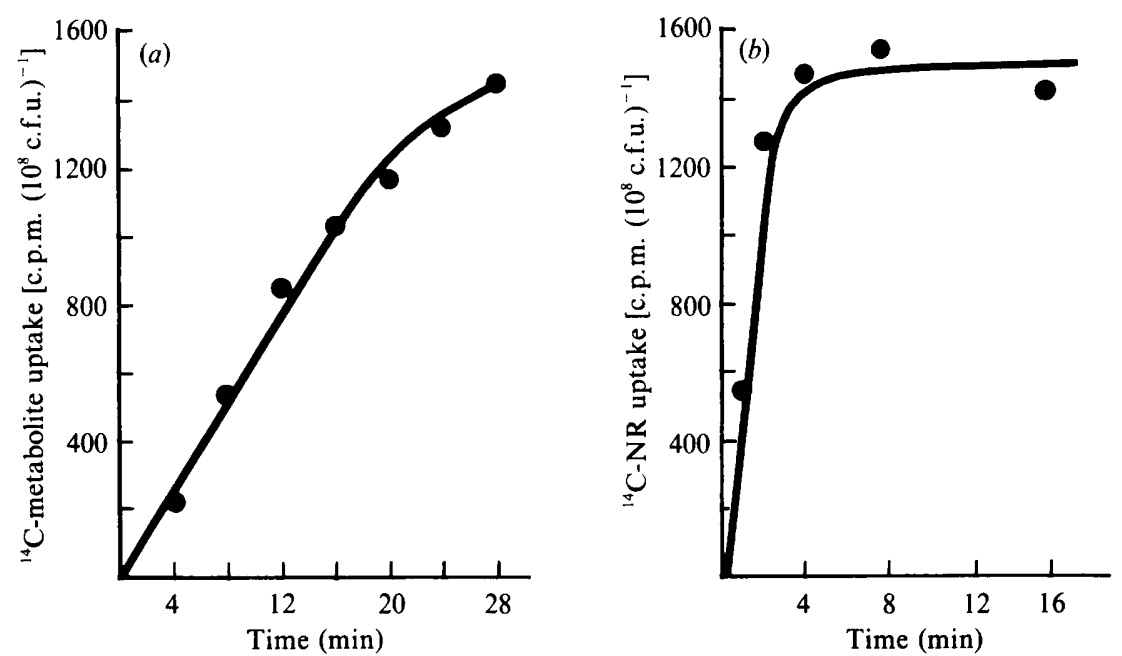

Fig. 2. Uptake of ${ }^{14} \mathrm{C}$-labelled metabolite from [carbonyl-14 C]NAD (a) and $\left[{ }^{14} \mathrm{C}\right] \mathrm{NR}($ b) by $H$. parainfluenzae. (a) The specific activity of $\left[\right.$ carbonyl $\left.{ }^{14} \mathrm{C}\right] \mathrm{NAD}$ was 48000 c.p.m. nmol ${ }^{-1}$ and the concentration was $0 \cdot 15 \mu \mathrm{M}$. Sampling was done immediately after the addition of label and at the times indicated on the abscissa. Each point represents the mean of triplicate samples, the SD of which was less than $5 \%$. (b) The specific activity of $\left[{ }^{14} \mathrm{C}\right] \mathrm{NR}$ was 112000 c.p.m. nmol ${ }^{-1}$ and the concentration was $0.15 \mu \mathrm{M}$. Sampling was done immediately after the addition of label and at the times indicated on the abscissa. Each point represents the mean of duplicate samples.

Table 2. Uptake of ${ }^{14} \mathrm{C}$-labelled metabolite from $\left[\right.$ carbonyl $\left.-{ }^{14} \mathrm{C}\right] N A D$ in the presence of pyridine nucleotides

\begin{tabular}{|c|c|c|}
\hline Pyridine nucleotide & $\begin{array}{l}\text { Molar ratio: } \\
\text { unlabelled compound/labelled NAD* }\end{array}$ & $\begin{array}{l}\text { Uptake } \\
{ }^{14} \mathrm{C} \text {-label } \\
\text { metabolit }\end{array}$ \\
\hline Control & & 100 \\
\hline $\begin{array}{l}\beta \text {-NAD } \\
\alpha \text {-NAD }\end{array}$ & $\begin{array}{l}10 \\
10 \\
50\end{array}$ & $\begin{array}{l}29 \\
78 \\
33\end{array}$ \\
\hline TNAD & $\begin{array}{r}2 \\
4 \\
8 \\
16\end{array}$ & $\begin{array}{l}73 \\
81 \\
42 \\
10\end{array}$ \\
\hline$\beta$-NMN & $\begin{array}{r}5 \\
10 \\
50\end{array}$ & $\begin{array}{r}15 \\
8 \\
2\end{array}$ \\
\hline NMN & $\begin{array}{r}10 \\
50 \\
100\end{array}$ & $\begin{array}{l}78 \\
85 \\
82\end{array}$ \\
\hline$\beta$-NAMN & $\begin{array}{r}2 \\
4 \\
8 \\
16\end{array}$ & $\begin{array}{r}105 \\
117 \\
98 \\
91\end{array}$ \\
\hline Nam & 16 & 89 \\
\hline
\end{tabular}

* The concentration of $\left[\right.$ carbonyl $\left.{ }^{14} \mathrm{C}\right]$ NAD was $0.15 \mu \mathrm{M}$ with a specific activity of $48000 \mathrm{c} . \mathrm{p} . \mathrm{m}$. nmol ${ }^{-1}$.

$\dagger$ Expressed as percentage of the control value, which was $0.59 \mathrm{pmol} \mathrm{min}^{-1}\left(10^{8} \mathrm{c.f} . \mathrm{u} .\right)^{-1}$. Each value is the mean of triplicate samples; SD values were less than $5 \%$ of the mean.

\section{Effect of pyridine nucleotides on uptake of label from [carbonyl $\left.-{ }^{14} C\right] N A D$}

The ability of pyridine nucleotides to block the uptake of ${ }^{14} \mathrm{C}$-labelled metabolite from [carbonyl $\left.{ }^{14} \mathrm{C}\right] \mathrm{NAD}$ was studied using varying molar ratios of these compounds (Table 2). The NAD analogues could interfere with the conversion of NAD to NMN/NR and/or with the 

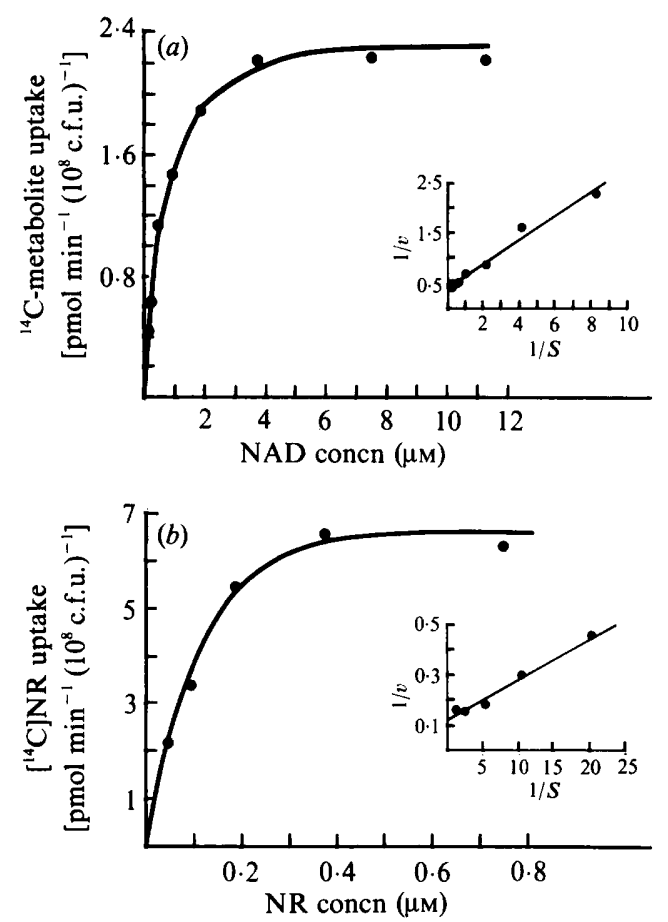

Fig. 3. Influence of substrate concentration on uptake of ${ }^{14} \mathrm{C}$-labelled metabolite from [carbonyl$\left.{ }^{14} \mathrm{C}\right] \mathrm{NAD}$ and $\left[{ }^{14} \mathrm{C}\right] \mathrm{NR}$ by $H$. parainfluenzae. (a) The concentration of the [carbonyl $\left.{ }^{-14} \mathrm{C}\right] \mathrm{NAD}$ was $0 \cdot 15$ $\mu \mathrm{M}$ at a specific activity of 48000 c.p.m. $\mathrm{nmol}^{-1}$. As the concentration of NAD was increased with the addition of unlabelled NAD the specific activity correspondingly decreased. The inset is a LineweaverBurk reciprocal plot $(y=0 \cdot 43+0 \cdot 23 x)$ fit by least-squares linear regression analysis. The values of $1 / v$ are expressed as [pmol $\left.\min ^{-1}\left(10^{8} \text { c.f.u. }\right)^{-1}\right]^{-1}$ and those of $1 / S$ are expressed as $\left(\mathrm{nmol} \mathrm{ml} \mathrm{m}^{-1}\right)^{-1} .{ }^{14} \mathrm{C}$ labelled metabolite is used to designate that part of NAD which is taken into the cell since it is clear from experiments shown below that NAD is not taken up intact. (b) The specific activity of $\left[{ }^{14} \mathrm{C}\right] \mathrm{NR}$ was 112000 c.p.m. nmol ${ }^{-1}$, which remained constant over the concentration range shown. Sampling was done 2 min after the addition of label. The inset is a Lineweaver-Burk reciprocal plot $(y=0 \cdot 12+0.016 x)$ fit by least-squares linear regression analysis. The values of $1 / v$ are expressed as

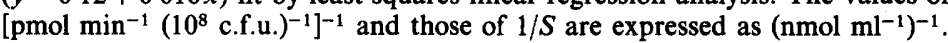

uptake of ${ }^{14} \mathrm{C}$-labelled metabolite. The nucleotides could interfere with the uptake of labelled compound but not with the conversion of NAD to NMN/NR (Kahn \& Anderson, 1986). TNAD decreased ${ }^{14} \mathrm{C}$-labelled metabolite uptake to a greater extent than $\alpha-\mathrm{NAD}$, probably because the former is a better substrate for nucleotide pyrophosphatase. $\beta$-NMN blocked ${ }^{14} \mathrm{C}$ labelled metabolite uptake far better than $\alpha$-NMN. $\beta$-NAMN and Nam reduced ${ }^{14} \mathrm{C}$-labelled metabolite uptake by approximately $10 \%$ at molar ratios of 16 . The results suggest that the transport system has specificity for the $\beta$-configuration of the glycosidic linkage of Nam nucleoside and an intact carboxamide group.

\section{Comparison of uptake of label from $\left[\right.$ carbonyl $\left.-{ }^{14} \mathrm{C}\right] N A D$ and $N\left[U-{ }^{14} C\right] A D$}

The uptake of ${ }^{14} \mathrm{C}$-metabolite from $\left[\right.$ carbonyl $\left.{ }^{14} \mathrm{C}\right] \mathrm{NAD}$ and from $\mathrm{N}\left[\mathrm{U}-{ }^{14} \mathrm{C}\right] \mathrm{AD}$ in the presence of unlabelled NAD, NMN, and AMP is shown in Table 3. When N[U-14C]AD was used, the uptake of label was not decreased in the presence of NMN, but was decreased with unlabelled NAD, and markedly decreased in the presence of 5- and 10-fold molar concentrations of AMP. When [carbonyl $\left.{ }^{-14} \mathrm{C}\right] \mathrm{NAD}$ was used, the uptake of label was markedly diminished in the presence of NMN but decreased only slightly in the presence of AMP. These data are consistent with the hypothesis that NAD is initially cleaved to NMN and AMP, prior to transport, and that NR or NMN is the actual metabolite that enters the cell. 
Table 3. Uptake of ${ }^{14} \mathrm{C}$-labelled metabolite from $N\left[U-{ }^{14} \mathrm{C}\right] \mathrm{AD}$ or $[$ carbonyl-14 $\mathrm{C}] \mathrm{NAD}$ in the presence of $N A D, N M N$, or $A M P$

\begin{tabular}{lccc}
\multicolumn{1}{c}{ Compound* } & Addition & Molar ratio & $\begin{array}{c}\text { Uptake of } \\
14 \text { C-labelled } \\
\text { metabolite }\end{array}$ \\
N[U-14 C]AD & & Control & 100 \\
& NAD & 10 & 27 \\
& NMN & 10 & 119 \\
& AMP & 5 & 14 \\
{$[$ carbonyl-14C]NAD } & AMP & 10 & 14 \\
& & Control & 100 \\
& NMN & 10 & 7 \\
& AMP & 10 & 81
\end{tabular}

* The concentration of both labelled compounds was $0 \cdot 15 \mu \mathrm{M}$ with a specific activity of 48000 c.p.m. nmol ${ }^{-1}$. $\dagger$ Expressed as percentage of the control value, which was $0.62 \mathrm{pmol} \mathrm{min}^{-1}\left(10^{8} \text { c.f.u. }\right)^{-1}$ for N[U-14C]AD and $0.47 \mathrm{pmol} \mathrm{min}^{-1}\left(10^{8} \mathrm{c.f} . \mathrm{u} \text {. }\right)^{-1}$ for $[$ carbonyl-14 C]NAD. Each value is the mean of triplicate samples; SD values were less than $5 \%$ of the mean.

\section{Uptake of $\left[\right.$ carbonyl $\left.-{ }^{14} \mathrm{C}\right] \mathrm{NR}$, and $\left[\right.$ carbonyl $\left.-{ }^{14} \mathrm{C}\right] \mathrm{Nam}$}

The uptake of ${ }^{14} \mathrm{C}$-labelled metabolite from [ carbonyl $\left.-{ }^{14} \mathrm{C}\right] \mathrm{NR}$ over time is shown in Fig. $2(b)$. Compared to the uptake from [carbonyl $\left.l^{-14} \mathrm{C}\right]$ NAD shown in Fig. $2(a)$ the uptake of label from $\mathrm{NR}$ was faster at the same concentration. The effect of NR concentration on the initial rate of uptake is illustrated in Fig. 3(b). A maximal rate of ${ }^{14} \mathrm{C}$-metabolite uptake was approached at NR concentrations above $0.4 \mu \mathrm{M}$, compared with $4 \mu \mathrm{M}$ for NAD. The $K_{\mathrm{m}}$ for transport of label from NR as derived from a double reciprocal plot (Fig. $3 b$, inset) was $0.14 \mu \mathrm{M}$ and the $V_{\max }$ was $8.5 \mathrm{pmol} \mathrm{min}-1$ (10 c.f.u. $)^{-1}$. Although the $K_{\mathrm{m}}$ is similar to that for NAD, NR is taken up at about a fourfold greater rate than NAD under saturation conditions. [carbonyl $\left.{ }^{14} \mathrm{C}\right] \mathrm{Nam}$ was not taken up by $H$. parainfluenzae (data not shown).

\section{$N A D$ breakdown by whole cells of $H$. parainfluenzae}

When whole cells of $H$. parainfluenzae were incubated with an excess of labelled NAD in the presence of $0.2 \mathrm{mM}$-DNP, increasing concentrations of NR were found in the extracellular filtrates (Fig. 4a). The concentration of NR increased in a linear fashion over $5 \mathrm{~h}$. The cells converted approximately one third of the NAD to NR, and about one third to Nam. The rest of the NAD was unchanged. NMN was not detected. When uptake was allowed to proceed (Fig. $4 b$ ), no NR was found in the extracellular filtrates. About half of the original radioactivity was converted to Nam over $5 \mathrm{~h}$ and the remainder was NAD. At $4{ }^{\circ} \mathrm{C}$, the NAD was unaltered by incubation with $H$. parainfluenzae. Cell membrane preparations of $H$. parainfluenzae break down NAD to NR and adenosine (data not shown). These results indicate that NAD is hydrolysed to NR extracellularly prior to uptake (Kahn \& Anderson, 1986). The amount of Nam found in the extracellular fluid was decreased when uptake of the NAD metabolite (i.e. NR or NMN) was inhibited. The extracellular Nam probably resulted from intracellular metabolism of the small amount of NR that is taken up in the presence of DNP (see Table 1).

\section{Synthesis of NAD}

The results of NAD synthesis experiments using cell extracts are shown in Fig. 5. NAD was rapidly produced when NR was used as a substrate, with NMN appearing as a transient intermediate. The reaction required ATP and $\mathrm{Mg}^{2+}$. The reaction did not proceed at $4{ }^{\circ} \mathrm{C}$ or when boiled cell extracts were used. NAD was produced from NMN (not shown) and both ATP and $\mathrm{Mg}^{2+}$ were required for the reaction. A large amount of Nam was also present in the reaction mixtures. About half of the labelled Nam found at the final time point was present in the preparation of the labelled NR used as the substrate. The additional Nam was probably produced by the action of nucleoside phosphorylase, an enzyme previously described in H. parainfluenzae (Bachur \& Kaplan, 1955). 


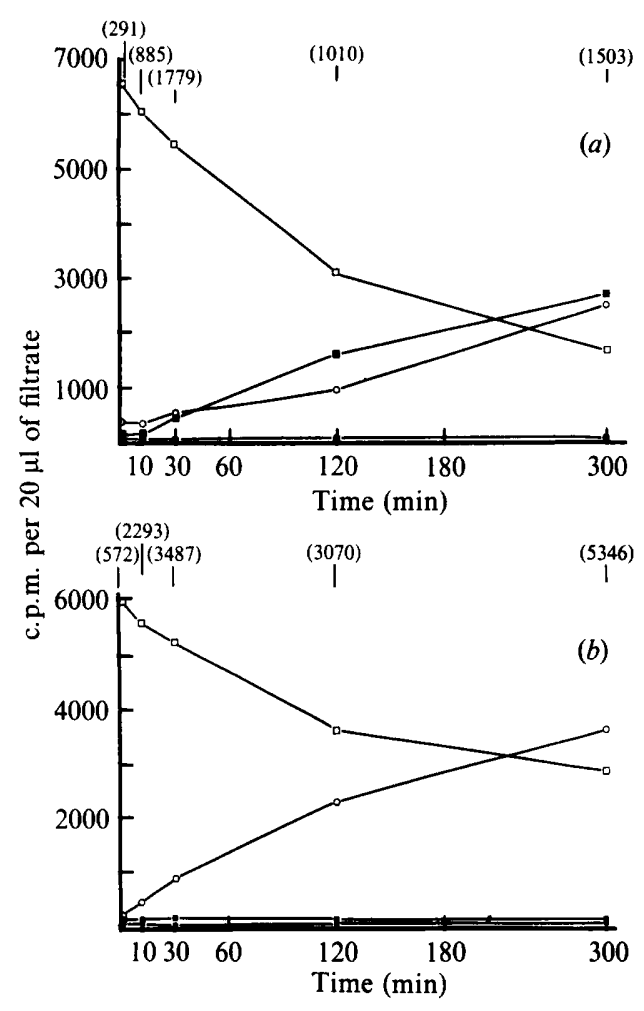

Fig. 4

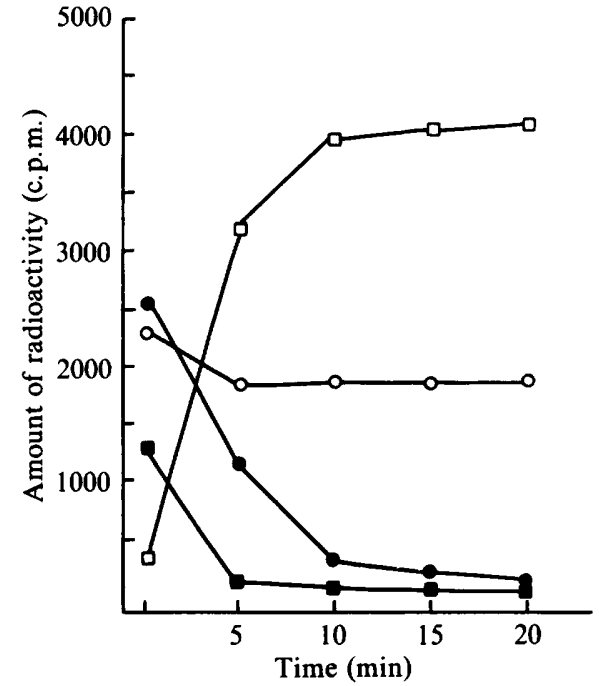

Fig. 5

Fig. 4. TLC of extracellular filtrate from $H$. parainfluenzae incubated with [carbonyl $\left.{ }^{14} \mathrm{C}\right] \mathrm{NAD}$. Whole cells of $H$. parainfluenzae $\left(8 \times 10^{8}\right.$ c.f.u. $\left.\mathrm{ml}^{-1}\right)$ were incubated with $60 \mu \mathrm{M}$-[ carbonyl-14 $\left.\mathrm{C}\right] \mathrm{NAD}$ (specific activity 8300 c.p.m. $\left.\mathrm{nmol}^{-1}\right)$ and $10 \mathrm{mM}-\mathrm{Mg}^{2+}$ at $37^{\circ} \mathrm{C}$. Samples $(500 \mu \mathrm{l})$ were filtered at various times. Samples $(20 \mu \mathrm{l})$ of filtrate were analysed by TLC. The amount of radioactive label taken up by the cells $\left(4 \times 10^{8}\right.$ c.f.u.) at each time is indicated in parentheses. (a) Conditions which inhibit uptake. DNP $(0 \cdot 2$ $\mathrm{mM}$ ) was present in the reaction mixture. (b) Conditions which promote uptake. Glucose ( $5 \mathrm{mM})$ was present in the reaction mixture. $\square, N A D ; \square, N R ; O, N a m ; 0, N M N$.

Fig. 5. In vitro synthesis of NAD from NR by $H$. parainfluenzae extract with 4 mM-ATP and 2 mM$\mathrm{Mg}^{2+}$ in $50 \mathrm{mM}$-Tris/ $\mathrm{HCl}$ buffer, $\mathrm{pH} 7.0$ and $\left[\right.$ carbonyl $\left.{ }^{14} \mathrm{C}\right] \mathrm{NR}$ (approx. $0.5 \mu \mathrm{Ci} \mathrm{ml}^{-1}$ ). The products were analysed by TLC system B. The amount of radioactivity at each time point is about 7000 c.p.m. per $10 \mu \mathrm{l}$ sample. By the time the $t_{0}$ sample can be sampled and boiled, over half of the NR has been converted to NMN or Nam. The reaction continues until all the remaining NR is converted to NAD. $\square, \mathrm{NAD} ; \mathrm{O}, \mathrm{Nam} ; \mathrm{O}, \mathrm{NMN} ; \mathbf{\square}, \mathrm{NR}$.

When TLC system C was used to analyse the reaction products, neither NAMN or NAAD was found as an intermediate. Similarly, when NMN was incubated with the cell extracts without the ATP and $\mathrm{Mg}^{2+}$, Nam was produced, but no NAMN was detected. NAD was not produced from Nam or nicotinic acid, even with the addition of PRPP and glutamine. Both Nam and nicotinic acid were unaltered in this system. Staphylococcus aureus cell extracts synthesized NAD from either nicotinamide or nicotinic acid under the same conditions (data not shown).

NAD was also synthesized in whole cells of $H$. parainfluenzae incubated with NR, as evidenced by TLC analysis of the toluene extracts. NAD and Nam were the only intracellular metabolites detected.

\section{Degradation of NAD}

Nam was the end-product of NAD metabolism both in toluene extracts of whole cells and in cell extracts incubated with NAD. Nicotinamidase activity was not detected in either system. A small amount of NR (about $5 \%$ of the radioactivity) appeared transiently as an NAD breakdown product in the cell extract system, but it was converted within 5 min to Nam, 
probably by nucleoside phosphorylase. The NR found in the cell extract experiments may have resulted from the nucleotide pyrophosphatase that breaks down NAD prior to uptake of NR. There was no spontaneous breakdown of NAD in the boiled extract controls.

Nam was also the only product found in the extracellular media after incubating the cells with labelled NAD (Fig. $4 b$ ). When NAD uptake was inhibited by deleting the glucose and adding DNP, NR was found in the extracellular media, and less Nam was produced (Fig. 4a). These results indicate that NAD glycohydrolase activity is intracellular, while hydrolysis of NAD to NR occurs extracellularly.

\section{DISCUSSION}

Since exogenous NAD, NMN, and NR support growth of $H$. parainfluenzae it was hypothesized that NAD is not taken up intact. The results of the uptake studies with [carbonyl$\left.{ }^{14} \mathrm{C}\right] \mathrm{NAD}$ and $\mathrm{N}\left[\mathrm{U}-{ }^{14} \mathrm{C}\right] \mathrm{AD}$ indicate that NAD is enzymically degraded to NMN or NR prior to being internalized. Further support for this hypothesis is provided by the greater reduction in uptake of ${ }^{14} \mathrm{C}$-labelled metabolite by unlabelled $\beta$-NMN than by unlabelled $\beta$-NAD at comparable molar ratios, and by the higher rate of uptake for labelled NR. Also the differential effects of AMP and NMN on the uptake of ${ }^{14} \mathrm{C}$-labelled metabolite from labelled NAD argue for cleavage of NAD prior to uptake. The affinities of the transport system for NR and NAD are similar as indicated by the $K_{\mathrm{m}}$ values of these compounds, but the $V_{\max }$ for NR uptake is several fold higher than for NAD uptake. Hydrolysis of NAD appears to be the rate limiting step for utilization of exogenous NAD. These conclusions are supported by the characterization of a nucleotide pyrophosphatase from $H$. influenzae (Kahn \& Anderson, 1986) that catalyses the hydrolysis of NAD to NMN and AMP. This enzyme was able to hydrolyse structural analogues of NAD where the pyridine ring was modified; however, compounds with modifications of the adenine ring were very poor substrates (Kahn \& Anderson, 1986). The enzyme required a diesterified pyrophosphate group. Both ADP and AMP inhibited enzyme activity and the former compound inhibited growth of $H$. influenzae in the presence of NAD.

The breakdown of NAD to NR occurs extracellularly, by the action of nucleotide pyrophosphatase at the cell surface (Kahn \& Anderson, 1986). The products of this enzyme are NMN and AMP. Probably NMN is rapidly hydrolysed to NR, perhaps by the action of alkaline phosphatase at the cell surface. The Nam nucleotide/nucleoside uptake system appears to have the following characteristics: (1) it is energy-dependent and carrier-mediated with saturation kinetics, (2) it is selective for the $\beta$-configuration of the glycosidic bond, and (3) it requires a carboxamide group on the pyridine ring. These charecteristics may be useful in designing specific antimetabolites that can block uptake of NR and/or inhibit subsequent intracellular NAD synthesis and therefore growth of Haemophilus species that require exogenous NAD.

The intercellular NAD synthetic pathway in $H$. parainfluenzae has not previously been reported but it has been described for $H$. influenzae (Kahn \& Anderson, 1986), $H$. pleuropneumoniae and $H$. parasuis (O'Reilly \& Niven, 1986b). Cell fractions derived from $H$. parasuis and $H$. pleuropneumonia can synthesize NAD from NMN or NR in the presence of ATP (O'Reilly \& Niven, 1986b). The catabolism of NAD, NMN or NR yielded Nam (O'Reilly $\&$ Niven, $1986 a, b$ ). These organisms have adapted to an environment in which NAD, NMN or NR is supplied by the host or by other micro-organisms. The observation that NR is taken up rather than NAD means that NAD must be resynthesized inside the cell. The results of these experiments suggest a synthetic pathway for NAD in H. parainfluenzae (Fig. 6), which is similar to that of other Haemophilus species that require exogenous NAD but otherwise unique among prokaryotes.

Salmonella typhimurium has also been shown to utilize NR for growth and NAD synthesis (Liu et al., 1982). However, $S$. typhimurium first phosphorylates NR to NMN, which is then converted to NAMN by direct deamination (Cruz et al., 1974; Hughes et al., 1983), or by sequential conversion of NR to Nam, nicotinic acid and NAMN (Hughes et al., 1983; Liu et al., 1982), as shown in Fig. 1. The NAMN is then converted to NAD through the common pathway. In our experiments there was no evidence of NAMN or NAAD formation in $H$. parainfluenzae. Nam and nicotinic acid remained unaltered in the in vitro system. 


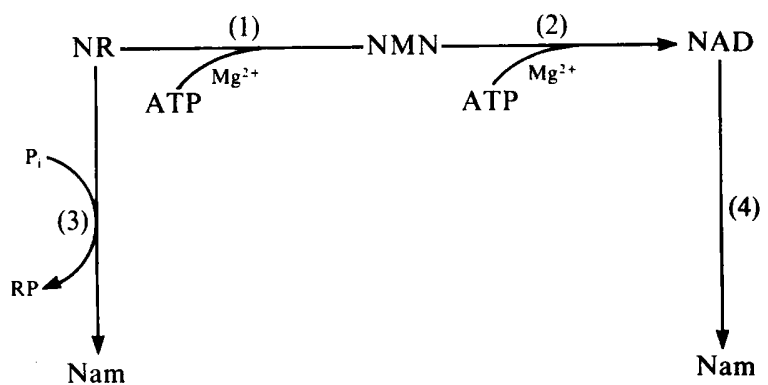

Fig. 6. Proposed pathway for NAD metabolism in $H$. parainfluenzae. Enzyme activities identified: 1 , nicotinamide ribonucleoside kinase; 2, NMN adenylyltransferase; 3, nucleoside phosphorylase; 4, NAD glycohydrolase. RP, ribose $5^{\prime}$-phosphate.

The proposed NAD pathway is consistent with the in vitro growth requirements of Haemophilus species requiring exogenous NAD. They will not grow on QA, which is an intermediate in all de novo NAD synthetic pathways that have been described. $H$. parainfluenzae also cannot utilize Nam, nicotinic acid or NAMN for growth, which is evidence against a pyridine nucleotide cycle in this organism.

The presence of a unique pathway among Haemophilus species that require exogenous NAD and the absence of a PNC suggest the possibility that NR analogues might be able to inhibit the growth of these organisms by blocking NR entry into the cell, by inhibiting intracellular NAD synthesis, and/or by serving as a substrate for the synthesis of an NAD analogue that has defective coenzyme activity.

We thank Richard Coulson, Ernest Hempel, and Joseph Tupper for helpful discussions during the development of these studies. Patricia Tyson and Gregory Palmer provided excellent technical assistance during parts of this work. We thank Richard Cross and Marcia Steinberg for their critical review of the manuscript.

\section{REFERENCES}

BACHUR, N. R. \& KAPLAN, N. O. (1955). Metabolism of diphosphopyridine nucleotide and related compounds in Hemophilus parainfluenzae (abstract). Bacteriological Proceedings 55, 116.

Chandler, J. R. \& Gholson, R. K. (1972). De novo biosynthesis of nicotinamide adenine dinucleotide in Escherichia coli: excretion of quinolinic acid by mutants lacking quinolinate phosphoribosyl transferase. Journal of Bacteriology 111, 98-102.

Cruz, L. J., Salabao, J. L., Flores, E. \& Olivera, B. M. (1974). Pyridine nucleotide metabolism: purification of a nicotinamide mononucleotidespecific deaminase. Technical Report no. 18, UP Natural Science Research Center, Quezon City, Philippines.

Cynamon, M. H., Sorg, T. B. \& Patapow, A. (1985). Utilization of exogenous nicotinamide adenine dinucleotide by Hemophilus parainfluenza. Clinical Research 33, 398A.

Foster, J. W. (1981). Pyridine nucleotide cycle of Salmonella typhimurium: in vitro demonstration of nicotinamide adenine dinucleotide glycohydrolase, nicotinamide mononucleotide glycohydrolase, and nicotinamide adenine dinucleotide pyrophosphatase activities. Journal of Bacteriology 145, 10021009.

Foster, J. W. \& MoAT, A. G. (1980). Nicotinamide adenine dinucleotide biosynthesis and pyridine nucleotide cycle metabolism in microbial systems. Microbiological Reviews 44, 83-105.
HerRiot, R. M., MEYer, E. Y., VoGt, M. \& ModAN, M. (1970). Defined medium for the growth of Haemophilus influenzae. Journal of Bacteriology 101, 513-516.

Hillyard, D., Rechsteiner, M., Manlapaz-Ramos, P., Imperial, J. S., Cruz, L. J. \& Olivera, B. M. (1981). The pyridine nucleotide cycle. Journal of Biological Chemistry 256, 8491-8497.

Hughes, K. T., Cookson, B. T., Ladika, D., Olivera, B. M. \& RoTH, J. R. (1983). 6-Aminonicotinamideresistant mutants of Salmonella typhimurium. Journal of Bacteriology 154, 1126-1136.

KAHN, D. W. \& ANDERSON, B. M. (1986). Characterization of Haemophilus influenzae nucleotide pyrophosphatase. Journal of Biological Chemistry 261, 6016-6025.

Kasarov, L. B. \& Moat, A. G. (1972). Convenient method for enzymatic synthesis of ${ }^{14} \mathrm{C}$-nicotinamide riboside. Analytical Biochemistry 46, 181-186.

KAY, W. W. (1971). Two aspartate transport systems in Escherichia coli. Journal of Biological Chemistry 245, 7373-7382.

Killian, M. (1980). Haemophilus. In Manual of Clinical Microbiology, 3rd edn, pp. 330-336. Edited by E. H. Lennette, A. Balows, W. J. Hausler, Jr \& J. P. Truant. Washington, DC: American Society for Microbiology.

LINEWEAVER, H. \& BURK, D. (1934). The determination of enzyme dissociation constants. Journal of the American Chemistry Society 56, 658-666. 
LiU, G., Foster, J., ManlaPaz-Ramos, P. \& Olivera, B. M. (1982). Nucleoside salvage pathway for NAD biosynthesis in Salmonella typhimurium. Journal of Bacteriology 152, 1111-1116.

Michal, G. (1978). Determination of Michaelis constants and inhibitor constants. In Principles of Enzymatic Analysis, pp. 29-40. Edited by H. U. Bergmeyer \& K. Gawehn. Weinheim, New York: Verlag Chemie.

Miksic, J. R. \& BRown, P. R. (1977). Complementary use of the reversed-phase and anion exchange modes of high-pressure liquid chromatography for studies of reduced nicotinamide adenine dinucleotide. Journal of Chromatography 142, 641-649.

O'ReIlly, T. \& NiveN, D. F. (1986a). Defining the metabolic and growth responses of porcine haemophili to exogenous pyridine nucleotides and precursors. Journal of General Microbiology 132, 807-818.
O'Reilly, T. \& Niven, D. F. (1986b). Pyridine nucleotide metabolism by extracts derived from Haemophilus parasuis and $H$. pleuropneumoniae. Canadian Journal of Microbiology 32, 733-737.

Preiss, J. \& HANDleR, P. (1958a). Biosynthesis of diphosphopyridine nucleotide. I. Identification of intermediates. Journal of Biological Chemistry 233, 488-492.

Preiss, J. \& Handler, P. (1958b). Biosynthesis of diphosphopyridine nucleotide. II. Enzymatic aspects. Journal of Biological Chemistry 233, 493500.

Sorg, T., Cynamon, M. \& Tyson, P. (1986). NAD metabolism in Hemophilus influenza and parainfluenza. American Society for Microbiology Annual Meeting (86), March 1986. Abstract D19. 